\title{
SOME DEMOGRAPHIC, PERSONAL AND CLASS CHARACTERISTICS AS PREDICTORS OF SCHOOL CLIMATE
}

\author{
Maja Brust Nemet, \& Tena Velki \\ Faculty of Education, Josip Juraj Strossmayer University of Osijek (Croatia)
}

\begin{abstract}
Being a teacher, like any job, has some of its specifics that contribute to whether the teachers feel more or less comfortable in their workplace. In general, teachers believe that the school climate describes a general perception of the situation at a workplace. School climate determines the quality of relationships and the feeling of comfort or discomfort in the relationships between the participants of the educational process. School climate is associated with the quality of the school environment, common perception of school behavior, and school management.

The aim of the study was to check the potential predictors of school climate among classroom teachers. Research included the contribution of demographic and class characteristics, stress experience, and social support as personal variables contributing to the prediction of the school climate. The study involved 311 classroom teachers $(97.7 \%$ female) from Croatia. During the State expert summit for teachers Strengthening of professional competences of classroom teachers, in June 2017, teachers completed the Scale of Social Resources, Scale for Measurement of Teachers' Stress Sources, and the Questionnaire of School Climate, assessing their own stress levels, social support, and school climate.

Research results showed that demographic and class characteristics are not crucial for predicting the school climate, however, school climate is connected to the teacher's experience of stress and support. Different sources of stress and social support proved to be significant predictors and accounted for $23.8 \%$ of the total variation of the school climate. A higher level of stress caused by the student's inappropriate behavior, a lower level of stress caused by the need for professional recognition, and the perception of greater social support predict a more positive school climate. Stress caused by inappropriate student behavior encourages teachers to change their behavior, but also to take responsibility for creating a positive classroom discipline through appropriate methods and forms of work which encourage student activity and promote a stimulating school climate. Teachers are aware that they can probably affect the stress of professional recognition a bit less, which creates a lesser need for stress for the climate to stay positive. Reducing the amount of stress is possible with the systematic support of competent institutions, experts, expert associates, and school principals, but also society as a whole, which should show greater respect for the teacher's calling.
\end{abstract}

Keywords: Social support, stress, school climate, teachers, Croatia.

\section{Introduction}

The studies of school climate started, more intensively, in the " 60 s of the 20th century in Anglo-Saxon countries (Domović, 2004). As one of the fundamental characteristics of extremely successful schools, Levine and Lezotte (1990) emphasize a productive school climate which is characterized by: environment in which order is reinstated; commitment of the staff towards a clearly articulated goal focused on achievement; problem solving orientation; cohesion, co-operation, consensus, communication, and collegiality; participation of staff in decision-making; with emphasis on work recognition. Positive school culture is conditioned by a stimulating climate characterized by humane relations and trust among the teaching community. Positive school culture is one of the factors that influence the development of pedagogical traits of teachers, and the quality of their educational work, relations between colleagues, working conditions at school. Teacher's emotional traits directly affect the emotional climate in a school. Teachers achieve them through working experience, experiential learning, and continuous professional development. 
Research about the connection between demographic characteristics and school climate mostly show that smaller schools in rural environments have some advantages over larger schools in urban environments (Nader, 2012). Schools in smaller communities have greater co-operation with parents, greater student involvement in school activities and a closer relationship between students and teachers, contributing to the development of a positive school climate, while other research (Othmana \& Muijsb, 2013) showed that teachers in rural environments perceive school climate as worse than teachers in urban environments. Research about the teachers' perception of school climate in terms of teacher's age, place of work, and the educational level shows that younger teachers perceive the school climate as worse, they feel less supported and believe they are less effective in work, while teachers older than 45 have a much more favorable perception of school climate. The same research also showed a significant difference in the assessment of the relationship with students regarding the place of work. High school teachers perceive a much better relationship with students, from the point of view of discipline (Orzea, 2016).

Research results (Stančić, Kiš-Glavaš \& Nikolić, 2015) show that students with disabilities are satisfied with the relationship and support of teachers, professional associates, and school principals. Teachers highly value an inclusive climate in schools, in order to provide adequate support to students with disabilities, active participation of students with disabilities in all educational activities of the school, taking into account the individual needs of each student. The results of the research (Kantorová, 2009) on the quality of school climate in Czech high schools showed that teachers are the most satisfied with all areas of school climate (overall school attitude, learning motivation, quality and competence of teachers, school rules and classroom discipline, solidarity of a class as a social group, architectural, aesthetic and hygienic aspects of the school), then by the level of satisfaction, follow parents who are somewhat less satisfied, while the greatest dissatisfaction exists among students. Job satisfaction achieves significant multiple correlations with the observed school climate characteristics, and no single predictor of school atmosphere is a significant at-risk level. Involvement, clarity, collegial cohesion and control proved to be predictor variables that confirm teacher's job satisfaction (Domović, 2004). Social support proved to be necessary to alleviate all causes of stress, and teacher's interest proved to be another source of stress among the researched 26 professions in the UK (Johnson, Cooper, Cartwright, Donald, Taylor \& Millet, 2005). Collie, Shapka and Perry (2012) proved that stress is related to school climate, which is mostly influenced by the motivation and behavior of students. The perceived stress is conditioned by the student behavior, i.e. more effective teaching equals a greater job satisfaction, and a lesser perception of stress. There is no statistically significant difference between the assessment of class and subject teachers when it comes to the perception of working conditions as a source of stress or when it comes to work relations. It has been proved that teacher's satisfaction with life or job is greater if there is a greater focus on the problem. The satisfaction is lesser if the focus is set on emotions, which increases insecurity, and teacher's unpreparedness for stress (Brkić \& Rijavec, 2012). Lazarus and Launier (1978) found out that the way people deal with stress has greater importance for their overall morale, social functioning and health than the number and strength of the stress episodes themselves.

Starting from the definition of school climate defined by Hoy and Hannum (1997) as relatively stable quality of the school environment, affecting the behavior of its members, and based on a common perception of behavior in school, influenced by formal and informal organizations, personality of participants and school management, the aim of this study was to check the potential school climate predictors for classroom teachers. The contribution of demographic characteristics and class characteristics in predicting the school climate and the experience of stress and social support as personality variables, personal characteristics contributing to the prediction of the school climate have been verified. The demographic characteristics of teachers (years of work experience and vocational qualifications), the characteristics of classes (number of students in the classroom and whether students with disabilities were present), the level of different sources of stress (inappropriate student behavior, professional recognition and workload) and social support have been tested.

\section{Method}

\subsection{Participants}

A total of 311 elementary school teachers (1st-4th grade elementary school, $97.7 \%$ female) participated in the research from all counties of the Republic of Croatia, most of them from Eastern Croatia $(57.4 \%)$. The majority of teachers were older than $41(61.6 \%)$ and more than 15 years of work experience $(68.6 \%)$.

\subsection{Instruments}

The Scale for measuring the source of teachers' stress (Sorić \& Mikulandra, 2004) measures the general source of teachers' stress caused by the job. It consists of 25 statements, and teachers need to show their agreement on the five-degree Likert type scale. In this case, 1 means "not at all stressful" and 5 "very stressful". The scale for measuring the source of teachers' stress can be divided into three subscales 
that measure different sources of stress: Inappropriate student behavior $(\mathrm{k}=6)$, Need for professional recognition $(\mathrm{k}=12)$ and Workload $(\mathrm{k}=7)$. The overall result is obtained on the basis of the arithmetic mean of all particles, and it is ranged from 1 to 5 , while the results for the subscales are obtained based on the arithmetic mean of the selected particles and it is also theoretically ranged from 1 to 5. The reliability of the scale for measuring the source of teachers' stress was, in our research Cronbach $\alpha=0.91$, while for each subscale it was: Inappropriate Student Behavior $\alpha=0.80$, Need for Professional Recognition $\alpha=0.84$ and Workload $\alpha=0,74$. The social provision scale (Nekić, 2008) measures the general perception of social support available to an individual, i.e. current relations with important persons (e.g. friends, family members, work colleagues, but does not specify any relationship). It consists of 24 statements, and answers are given on a 4-degree Likert type scale, with 1 meaning - fully agrees, and 4 - completely disagree. The overall result is obtained on the basis of the arithmetic mean of all particles, and it is theoretically ranged from 1 to 4 . The reliability of the social provision scale in our study was Cronbach $\alpha=0.89$. The questionnaire of school climate (QSC (in Croatian UŠK) -Teacher's version, Velki, 2012) measures the global dimension of school climate, including the relationship between students and teachers, and the relationship between school staff, the sense of belonging to school, learning atmosphere, parent involvement, predicting student's future based on schooling, and professional development. It consists of 18 statements, and teachers need to show their level of agreement, based on a five-degree Likert scale, with 1 meaning "completely agree" and 5 " completely disagree". The overall result is obtained based on the arithmetic mean of all particles and it is theoretically ranged from 1 to 5 . The reliability of the questionnaire - teachers' version was, in our research, Cronbach $\alpha=0.88$.

\subsection{Procedure}

Data gathering took place during the State expert summit for teachers Strengthening of professional competences of classroom teachers held from 19 to 21 June 2017 in Osijek. Data was gathered in a group, and the questionnaire completed in approx. about 20 minutes. All of the participants agreed to fill in the questionnaires. The research was completely voluntary and anonymous.

\section{Results}

Table 1 shows descriptive data for measured variables. Testing of normality of distribution showed that the distribution of major research variables does not deviate significantly from the normal distribution. Asymmetric indexes did not exceed values greater than 2.00, and since the distributions were asymmetric on the same side, we decided on the parametric statistics (Field, 2009).

Table 1. Descriptive data for measured variables $(N=311)$.

\begin{tabular}{lllllll}
\hline variables & Min & Max & M & SD & asymmetry & flatness \\
\hline school climate & 2.17 & 5.00 & 4.07 & .428 & -.500 & 1.286 \\
\hline inappropriate student behavior & 1.00 & 4.83 & 3.05 & .758 & -.295 & -.121 \\
\hline need for professional recognition & 1.27 & 4.82 & 3.03 & .599 & .001 & .290 \\
\hline workload & 1.14 & 4.57 & 3.10 & .662 & -.162 & -.285 \\
\hline social support & 2.00 & 4.00 & 3.48 & .379 & -.895 & .438 \\
\hline
\end{tabular}

The teachers mostly had between 16 and 25 years of work experience (37.9\%) and more than 26 years of work experience (30.7\%), while a small number had between 6 and 15 years of work experience $(20.4 \%)$, and the least had less than 5 years of work experience (11\%). Most teachers did not have senior vocational qualifications $(54.8 \%)$, mentors totaled $26.8 \%$, while counselors were $18.4 \%$. Most of the teachers $(51.3 \%)$ worked in middle-sized classes (10 to 20 students), followed by large classes $(33.2 \%, 21$ to 30 students) and least worked in small classes with less than 10 students (15.5\%). At least one student with disabilities was represented in $48.2 \%$ of the classes.

To check the potential predictors of school climate, a regression analyses in two steps was made (Table 2). In the first step, the contribution of the demographic characteristics of the teacher (working time and vocational qualifications) and the characteristics of the class in which they work (class size and the inclusion of students with disabilities) are checked. The second step assessed levels of different stress sources, and the perceived social support as the predictors of the school climate. The demographic characteristics of teachers, and the characteristics of the class did not prove to be significant predictors of the school climate. 
Table 2. Regression analysis for predicting the school climate.

\begin{tabular}{llc}
\hline predictors & & School climate $-\beta$ \\
\hline demographic & work experience & -0.005 \\
characteristics & professional vocation & -0.063 \\
class characteristics & class size & 0.052 \\
& students with disabilities in the class & -0.007 \\
\hline Regression model & $\mathrm{R}=0.078 ; \mathrm{R}^{2}=0.006 ; \mathrm{R}^{2}$ kor $=0.000 ;$ & $\mathrm{F}_{(4,307)}=0.462 ; \mathrm{p}>0.01$ \\
\hline demographic & work experience & 0.061 \\
characteristics & professional vocation & $-0 ., 055$ \\
class characteristics & class size & -0.023 \\
& students with disabilities in the class & 0.059 \\
\hline & inappropriate student behavior & $0,264 * *$ \\
stress & need for professional recognition & $-0.317 * *$ \\
& workload & $-0,041$ \\
& social support & $0,386^{* *}$ \\
\hline Regression model (final solution) $\mathrm{R}=0.508 ; \mathrm{R}^{2}=0.258 ; \mathrm{R}^{2} \mathrm{kor}=0.238 ;$ & $\mathrm{F}_{(8,303)=12.819 ; \mathrm{p}<0.01}$ \\
\hline $\mathrm{p}>0,05 ; * * \mathrm{p}>0,01$ & $\quad$ &
\end{tabular}

Demographic characteristics and class characteristics did not show as significant school climate predictors. They have no contribution to explaining the school climate. Different sources of stress and social support have shown as significant school climate predictors and accounted for $23.8 \%$ of the total variation of the school climate. A higher level of stress caused by the student's inappropriate behavior, a lower level of stress caused by the need for professional recognition and the perception of greater social support predict a more positive school climate.

\section{Discussion}

Research results showed that demographic characteristics of teachers, such as years of work experience, age and professional vocation of teachers, are not connected to school climate, as opposed to research (Orzea, 2016) where younger teachers perceive an unfavorable school climate. In this research, it can be concluded that the perception of school climate is associated with some other predictors because work experience, age, professional advancement, students per class and the inclusion of students with disabilities in classes is of no importance to the perception of the school climate. If objective and permanent demographic characteristics are not connected with school climate, then it is possible to intervene in predictors that change the school climate by providing support and additional training. In the research conducted, the school climate was associated with the teacher's experience of stress and support as well as in previous research (Domović, 2004, Johnson et al., 2005). Different sources of stress and social support have proven to be significant predictors of climate school in this research, i.e. higher levels of stress are caused by inappropriate student behavior and lower levels of stress by the need for professional recognition, while the perception of greater social support predicts a more positive school climate. Stress caused by inappropriate student behavior encourages teachers to change their behavior, but also to take responsibility for creating positive discipline in the classroom through appropriate methods and forms of work that encourage student activity, and thus a stimulating school climate, as demonstrated in research by Collie, Shapka and Perry (2012). Therefore, when teachers are more focused on solving problems and less on emotions, they are surer in the decisions they make, more prepared for stress and are more satisfied with their job (Brkić \& Rijavec, 2012), while at the same time the way of dealing with stress becomes more important than the amount and strength of stress (Lazarus \& Launier, 1978). Teachers are aware that they may be less likely to affect stress affected by the need for professional recognition, so that area needs to be less affected, in order to keep the climate positive. Reducing the amount of stress is possible with the systematic support of competent institutions, experts, expert associates and school principals (Johnson et al., 2005), but also the society as a whole, which should show greater respect for the teachers.

The disadvantages of the study are the uneven number of male and female participants, which is common in research among teachers, where women dominate. Research results would be more relevant is more methods were used, not only the method of self-assessment. The advantages of this research are scientific justification, meaningful and grounded operationalization of the main variables, and the construction and application of appropriate instrumentation on a representative sample. It is recommended, for future research, to use additional assessment methods (e.g. with subject teachers, high school teachers, principals, expert associates, but also students) as well as verifying some additional demographic characteristics of teachers, and class characteristics which can potentially affect the stress of the classroom teacher. 


\section{Conclusions}

One of the specific competencies of a teacher is the ability to create a climate conducive to learning and humane relationships in school. Research results show that demographic and classroom characteristics are not crucial for the school climate, but the school climate is connected to the teacher's experience of stress and support. A positive school climate is predicted by a higher level of stress caused by the student's inappropriate behavior, a lower level of stress caused by the need for professional recognition, and the perception of greater social support. Therefore, it is necessary to strengthen the teachers, through formal and informal training, for appropriate problem solving and ways of dealing with stress, as well as to provide them with continuous social support. Seeing that stress has proven to be crucial to the perception of school climate, future research will explore potential predictors of teacher stress, such as demographic and class characteristics, whether there are differences in stress levels in the region of Croatia in which they work, and check the correlation between stress levels with school climate and social support.

\section{References}

Brkić, I. \& Rijavec, M. (2012). Izvori stresa, suočavanje sa stresom i životno zadovoljstvo učitelja razredne i predmetne nastave [Sources of stress, ways of facing stress and life satisfaction of primary school teachers]. Napredak, 152(2), 211-225.

Collie, R. J., Shapka, J. D. \& Perry, N. E. (2012). School Climate and Social-Emotional Learning: Predicting Teacher Stress, Job Satisfaction, and Teaching Efficacy. Journal of Educational Psychology, 104(4), 1189 -1204.

Domović, V. (2004). Školsko ozračje i učinkovitost škole [School climate and school efficiency]. Jastrebarsko: Naklada Slap.

Hoy, W. K. \& Hannum, J. W. (1997). Middle school climate: An empirical assessement of organizational health and student achievement. Educational Administration Quarterly, 33(3), 290-311.

Johnson, S., Cooper, C., Cartwright, S., Donald, I., Taylor, P. \& Millet, C. (2005). The experience of work-related stress across ocupations. Journal of Managerial Psychology, 20(2), 178-187.

Kantorová, J. (2009). The school climate- theoretical principles and research form the perspective of students, teachers and parents. Odgojne znanosti, 11(1), 183-189.

Klein, J. \& Cornell, D. (2010). Is the link between large high schools and student victimization an illusion? Journal of Educational Psychology, 102, 933-946.

Lazarus, R. S., \& Launier, R. (1978). Stress-related transaction between person and environment. In L. A. Pervin \& M. Lewis (Eds.), Perspectives in interactional psychology, pp. 287-327. New York: Plenum.

Levine, D. U., \& Lezotte, L. W. (1990). Unusually effective schools: A review and analysis of research and practice. Madison, WI: The National Center for Effective Schools Research and Development.

Nekić, M. (2008). Skala socijalnih zaliha. In Z. Penezić, V. Ćubela Adorić, A. Proroković, \& I. Tucak Junaković (Eds.). Zbirka psihologijskih skala i upitnika, Svezak 4. [The collection of psychological scales and questionnaires, Volume 4], pp. 49-58. Zadar: Sveučilište u Zadru.

Orzea, I. E. (2016). Teachers' Perspective on School Climate. Bulletin of the Transilvania University of Brasov. Series VII: Special Issue, 9, 147-152.

Othmana, M. \& Muijsb, D. (2013). Educational quality differences in a middle-income country: the urban rural gap in Malaysian primary schools. School Effectiveness and School Improvement, 24, 104-122.

Sorić, I. \& Mikulandra, I. (2004). Skala za mjerenje izvora nastavničkog stresa. In A. Proroković, K. Lacković-Grgin, V. Ćubela Adorić, \& Z. Penezić (Eds.). Zbirka psihologijskih skala i upitnika, Svezak 2. [The collection of psychological scales and questionnaires, Volume 2.], pp 62-69. Zadar: Sveučilište u Zadru.

Stančić, Z., Kiš-Glavaš, L. \& Nikolić, B. (2015). Some indicators of satisfaction with the support system for students with disabilities in Secondary Education in Croatia. Revista Electrónica Interuniversitaria de Formación del Profesorado, 18(1), 123-140. doi: http://dx.doi.org/10.6018/reifop.18.1.214361

Velki, T. (2012). Provjera ekološkoga modela dječjega nasilničkoga ponašanja prema vršnjacima. [Checking the ecological model of child violent behavior by peers]. (Doctoral thesis). Zagreb: Filozofski fakultet. 